\title{
PRELIMINARY OBSERVATIONS ON THE METAL CONTENT IN SOME MILK SAMPLES FROM AN ACID GEOENVIRONMENT
}

\author{
PENTTI ALHONEN, SÄDE MANTERE-ALHONEN and ANTTI VUORINEN
}

\begin{abstract}
ALHONEN, PENTTI, MANTERE-ALHONEN, SÄDE and VUORINEN, ANTTI 1997: Preliminary observations on the metal content in some milk samples from an acid geoenvironment. Bull. Geol. Soc. Finland 69, Part $1-2,31-41$.

The metal content of some milk samples was analyzed from areas of acid sulphate soils along the course of the river Kyrönjoki in western Finland. Comparative analyses were made with samples from the Artjärvi-Porlammi area. The variations of analyzed metals $\mathrm{Al}, \mathrm{Ba}, \mathrm{Ca}, \mathrm{Cr}, \mathrm{Cu}, \mathrm{Fe}, \mathrm{K}, \mathrm{Mg}, \mathrm{Mo}$, $\mathrm{Na}, \mathrm{Sr}$ and $\mathrm{Zn}$ are not great in both areas except that of $\mathrm{Al}$, which is clearly associated with the acid environment in the Kyrönjoki valley. The portions of these elements in milk are relatively high as compared with data from literature. It is obvious that they show environmental contamination. Under acid circumstances the metals in milk may create serious geomedical problems.
\end{abstract}

Keywords: environmental geology, acid sulfate soils, heavy metals, pollution, toxicity, milk, medical geology, multiple sclerosis, Kyrönjoki, Finland

Pentti Alhonen and Antti Vuorinen: Department of Geology, P.O. Box 11, FIN-00014 University of Helsinki.

Säde Mantere-Alhonen: Department of Food Technology / Dairy Technology P.O Box 27, FIN-00014 University of Helsinki.

\section{INTRODUCTION}

The main purpose of the present paper was to analyze the contents of certain metals in cow milk samples collected from farms which are situated in areas of acid sulphate soils along the course of the river Kyrönjoki in western Finland, southeast of the town of Vaasa (Fig. 1). The study is the late st in the series of investigations of the relationship between the prevalence of multiple sclerosis (MS) and acid geoenvironment (see Häsänen et al. 1986). The toxicity of sulphate soils seems to be a risk factor for human health in the drainage basin of the river Kyrönjoki, where the prevalence figures of this disease in some communes are very high (Häsänen et al. 1986: 264). Some raw milk samples were also collected from the low-prevalence area of Artjärvi-Porlammi in southern Finland for comparison. 


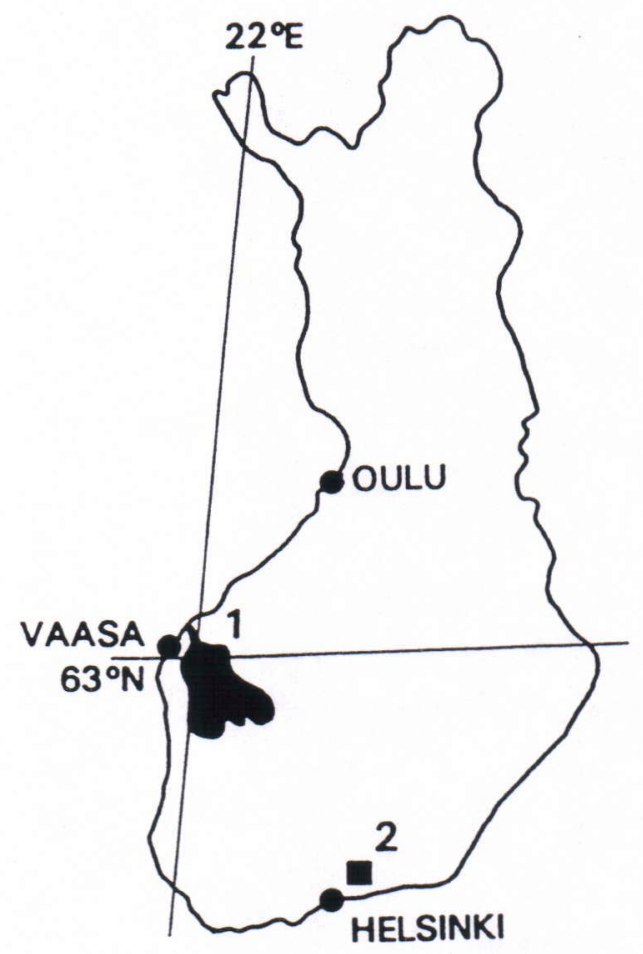

Fig. 1. A map showing the location of the river Kyrönjoki drainage basin (I) and the reference area of Artjärvi-Porlammi (2).

The metal content of milk and dairy products has been studied to some extent in Finland (e.g. Antila and Antila 1971; Varo et al. 1980). The samples were collected from dairies representing the most important production areas in Finland. The analytical list published by Varo et al. (1980: Table 1) covers almost all metals analyzed in this study with exception of $\mathrm{Ba}, \mathrm{Na}$ and $\mathrm{Sr}$. However, environmental contamination caused by metals in Finnish raw milk has not been studied extensively, and the influence of the chemical elements of sediments in the food chain on milk is insufficiently known. Certain geological deposits such as till, sand, silt, clay and peat form an important source of metals for different kinds of food, and the problem is very likely connected with their geochemistry.

Large areas in the Kyrönjoki valley are covered with fine-grained sulphide-bearing sediments. The contents of soluble elements in these Litorina clays are high and they have caused, due to intensive land use, problems to agriculture (e.g. Erviö 1975). In addition, the geochemical difference is most marked between the Litorina clay and the Yoldia or Ancylus clays (Salminen et al. 1997). It should be also mentioned that the heavy metals are in a more soluble form in clays than e.g. in till.

\section{GEOLOGY OF THE STUDY AREA}

The drainage basin of the river Kyrönjoki covers $4920 \mathrm{~km}^{2}$, of which $47 \%$ is made up of forests, $26 \%$ of mires, $24 \%$ of arable land, $2 \%$ of built-up areas and $1 \%$ of lakes (Heikkilä 1991). Svecofennian plutonic rocks and schists are most common rock types in the area. The dominating superficial deposits are till, silt and clay. Glaciofluvial deposits are limited to near watersheds. Raised bogs are the dominant mire type. Flood deposits and sulphide clays formed in the pre-Baltic Litorina Sea (7500about 3000 B.P.) are also common.

The water of the river Kyrönjoki has a high humus content due to drainage from extensive mire areas. Besides, the river water is exceptionally acid. Its $\mathrm{pH}$ is usually about 5.5 , but can frequently fall below 4.0 (Heikkilä 1991). High sulphate, iron and aluminium concentrations have been measured in the water of the river Kyrönjoki (Häsänen et al. 1986). Its quality is poor and experimental studies have shown that a high portion of the extractable contents of several elements is mobilized at oxidation (Åström 1996). Likewise, the soils in its environment have high contents of these chemical elements and compounds.It is also worth mentioning that drainage of peatlands has increased the erosion and the organic matter of the river Kyrönjoki.

Clay covers about $43 \%$ of the surface sediments in the reference area of Artjärvi-Porlammi. On the slopes, the varved clay deposited in the Baltic Ice Lake forms the topmost soil layer, whereas in flat basins the surface soil is composed of younger homogeneous clays. These were deposited in the Yoldia Sea and the Ancylus Lake in 
the history of the Baltic (Tynni et al. 1976). The pastures in this reference area are situated on these sediments, in which the Ancylus clays seem to be very common.

\section{MATERIAL AND METHODS}

Milk samples were collected from 5 farms situated in the communes of Isokyrö and Ylistaro in the Kyrönjoki valley on 4 September 1991, when animals were still being pastured. The other series of milk samples were collected from the same farms in February (1992) during the indoor feeding of the cows. Similarly, two mixed milk samples for comparison were analyzed from the farms situated in the parishes Artjärvi and Porlammi in southern Finland. The fodder used during the winter originated mainly from fields of the same area.

The analyses were made from frozen-stored milk at the Geochemical Laboratory, Department of Geology, University of Helsinki (Dr. Antti Vuorinen) as follows: $200 \mathrm{~g}$ of milk was evaporated on water bath in Teflon dishes, and the residues were homogenized. Thereafter, $5 \mathrm{~g}$ of the sample was weighed into a flat bottom flask, $3 \mathrm{ml}$ of $100 \%$ nitric acid (Merck No. 4S5) was added, and the sample was heated gently on a hot plate. This procedure was repeated with a new portion of nitric acid until the sample was decomposed. Five $\mathrm{ml}$ of $65 \%$ nitric acid (Merck, suprapur, No. 847) was added, the solution was diluted with $15 \mathrm{ml}$ of double-destilled water, filtered with filter-paper (Schleicher \& Schull, No. 597) and decanted into a volumetric flask of $50 \mathrm{ml}$.

Chemical analyses were accomplished by inductively-coupled plasma emission spectrometry (Jobin Yvon 70+). The total concentrations were determined for $\mathrm{Al}, \mathrm{Ba}, \mathrm{Ca}, \mathrm{Cr}, \mathrm{Cu}, \mathrm{Fe}, \mathrm{Kl}$, $\mathrm{Mg}, \mathrm{Mo}, \mathrm{Na}, \mathrm{Sr}$ and $\mathrm{Zn}$.

\section{RESULTS}

The variations in the concentrations of analyzed metals are shown as histograms in Figs 2-13. The iron content fluctuated from $345 \mu \mathrm{g} / \mathrm{kg}$ to 680 $\mu \mathrm{g} / \mathrm{kg}$ in the outdoor feeding samples (the indoor feeding samples contained 190-660 $\mu \mathrm{g} / \mathrm{kg}$, Fig. 2). Aluminium shows the highest concentration (2390 $\mu \mathrm{g} / \mathrm{kg}$ ) in sample 5 for the outdoor feeding season in the Kyrönjoki valley, whereas the $\mathrm{Al}$ values in the samples from Artjärvi-Porlammi area are very low (Fig. 3). The zinc content is higher in the indoor feeding samples from the Kyrönjoki valley. The highest $\mathrm{Zn}$ value was found in an outdoor feeding sample $(5035 \mu \mathrm{g} / \mathrm{kg})$ from the reference area (Fig. 4).

Fig. 5 shows the molybdenum content of milk samples. The Mo values have a maximum in the Kyrönjoki area (sample 5 for indoor feeding). The chromium concentrations are generally low. However, in sample 5 from the Kyrönjoki valley there is a clear maximum of $80 \mu \mathrm{g} / \mathrm{kg}$ in the indoor feeding samples while the highest concentration in the outdoor feeding samples is from the reference area (Fig. 6). The values obtained for the $\mathrm{Cu}$ content show a maximum in both outdoor and indoor feeding samples (Fig. 7).

Sodium and potassium show quite similar figures in the milk samples from farms of both areas. The values for the pasture season are higher in the reference area of Artjärvi-Porlammi than in the Kyrönjoki valley (Figs 8 and 9). The magnesium content in the milk samples from both areas is low. However, in sample 8 there is an outdoor maximum value of $934 \mu \mathrm{g} / \mathrm{kg}$ (Fig. 10). The concentrations of calcium were higher in the indoor feeding samples than in that of the outdoor feeding samples from the Kyrönjoki valley. Ca levels in the reference area show higher values during the pasture season (Fig. 11). The barium content of the milk samples representing the outdoor feeding varied between $28-280 \mu \mathrm{g} / \mathrm{kg}$. Sample 8 shows the maximum value in the Artjärvi-Porlammi area (Fig. 12). The limits of variation of strontium content were $220-768 \mu \mathrm{g} / \mathrm{kg}$ for outdoor and 373$1180 \mu \mathrm{g} / \mathrm{kg}$ for indoor feeding milk samples in the Kyrönjoki area. The maximum $\mathrm{Sr}$ value in the reference sample 8 was $1200 \mu \mathrm{g} / \mathrm{kg}$ (Fig. 13). 
34 Pentti Alhonen et al.

\section{$\mathrm{Fe} \mu \mathrm{g} / \mathrm{kg}$}

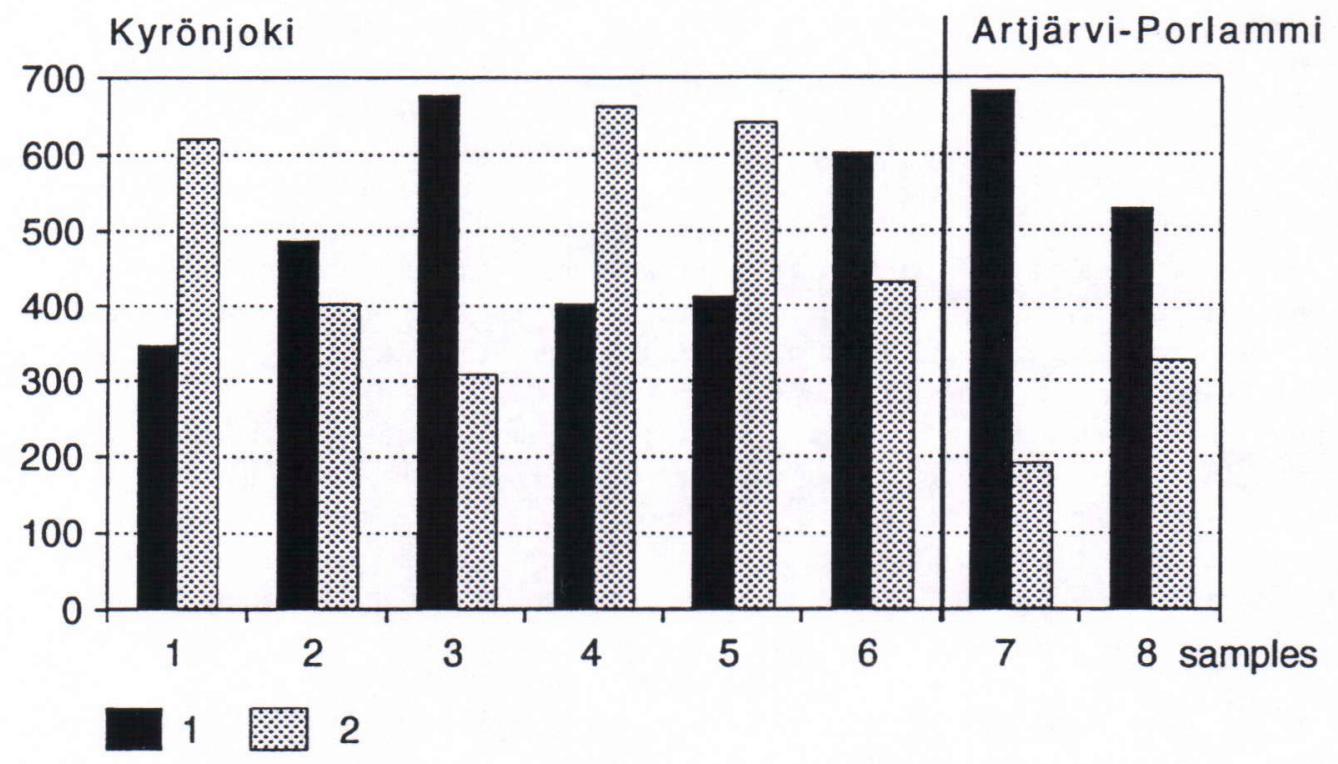

Fig. 2. Iron content of analyzed milk samples. $1=$ outdoor feeding, $2=$ indoor feeding.

\section{$\mathrm{Al} \mu \mathrm{g} / \mathrm{kg}$}

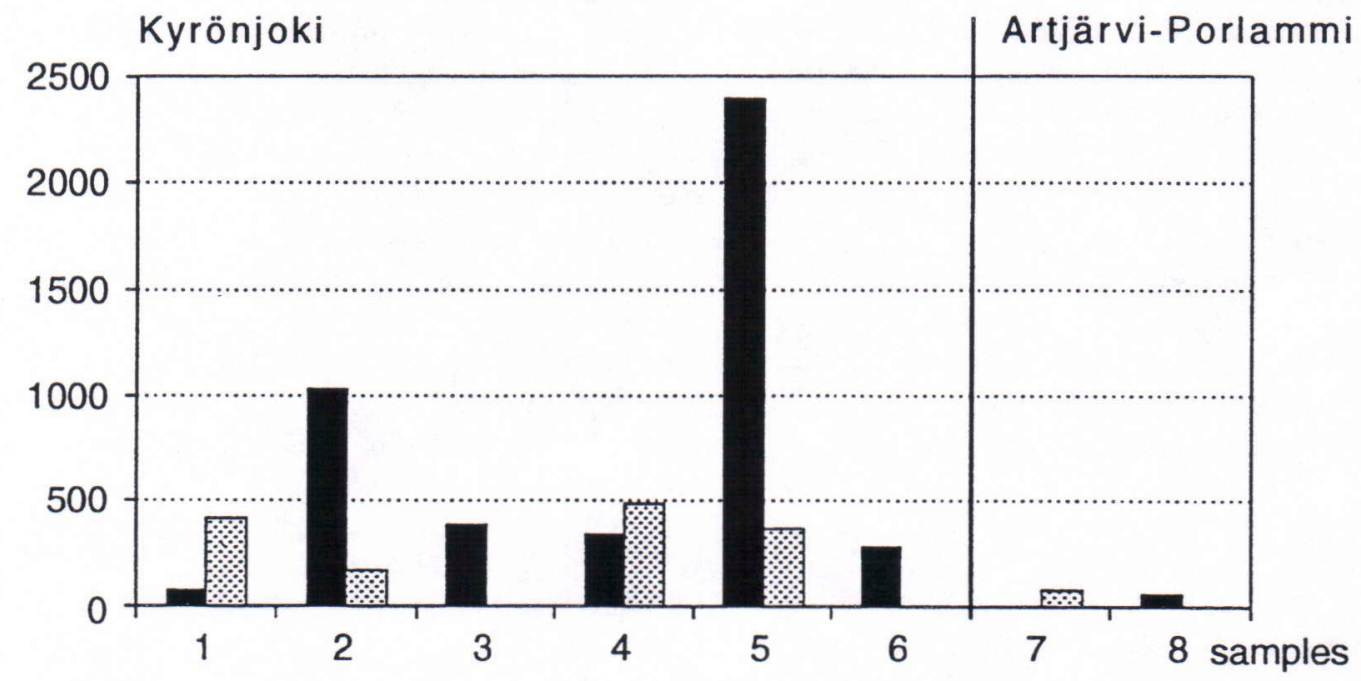

Fig. 3. Aluminium content of analyzed milk samples. 


\section{$\mathrm{Zn} \mu \mathrm{g} / \mathrm{kg}$}

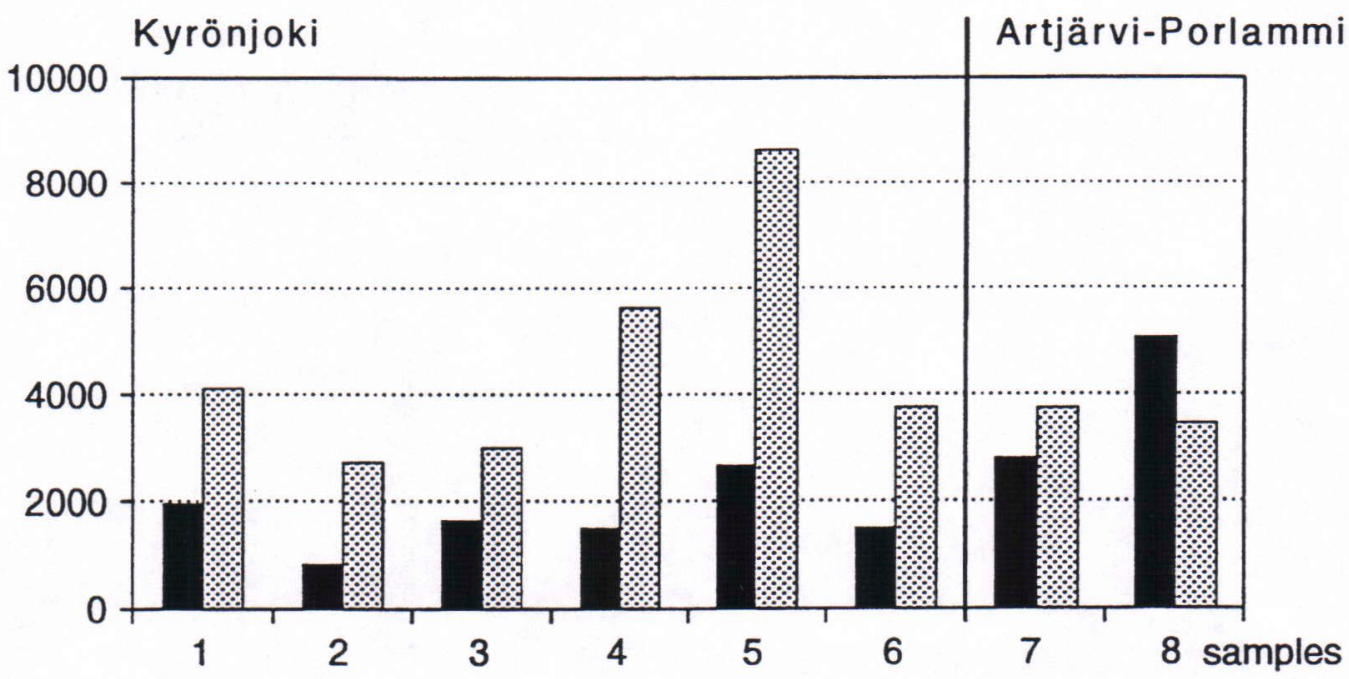

Fig. 4. Zinc content of analyzed milk samples.

\section{Mo $\mu g / k g$}

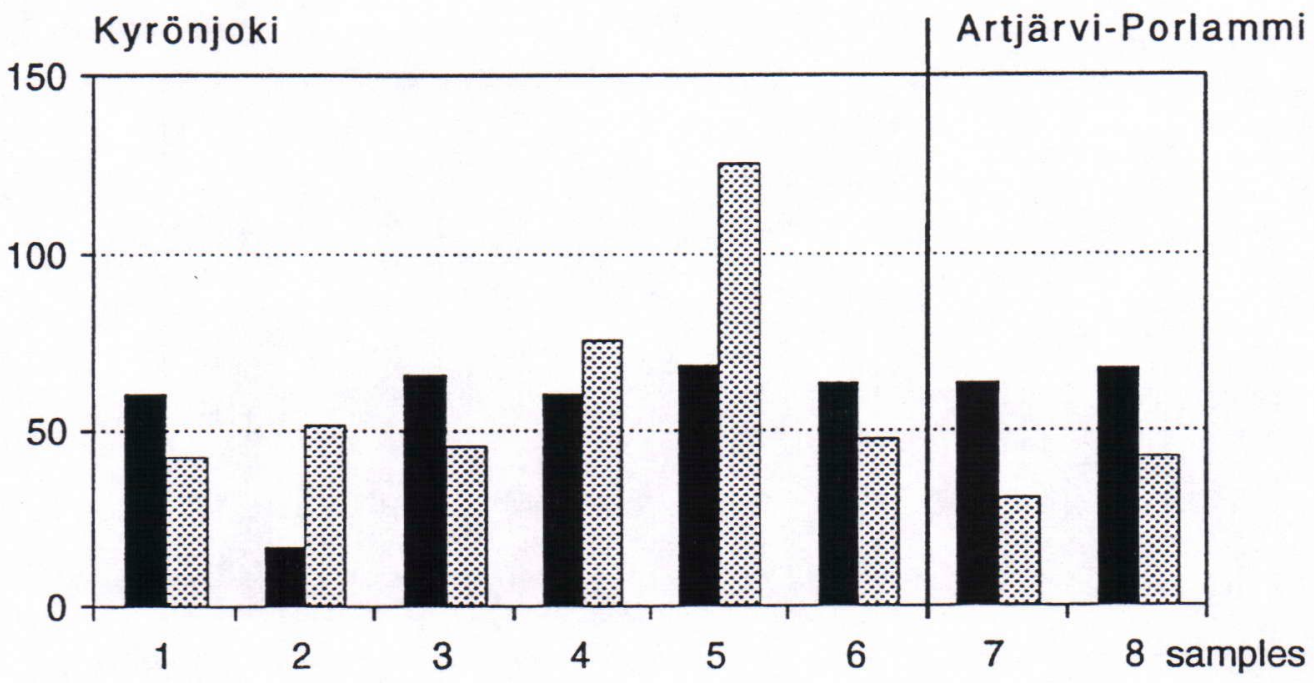

Fig. 5. Molybdenum content of analyzed milk samples. 


\section{$\mathrm{Cr} \mu \mathrm{g} / \mathrm{kg}$}

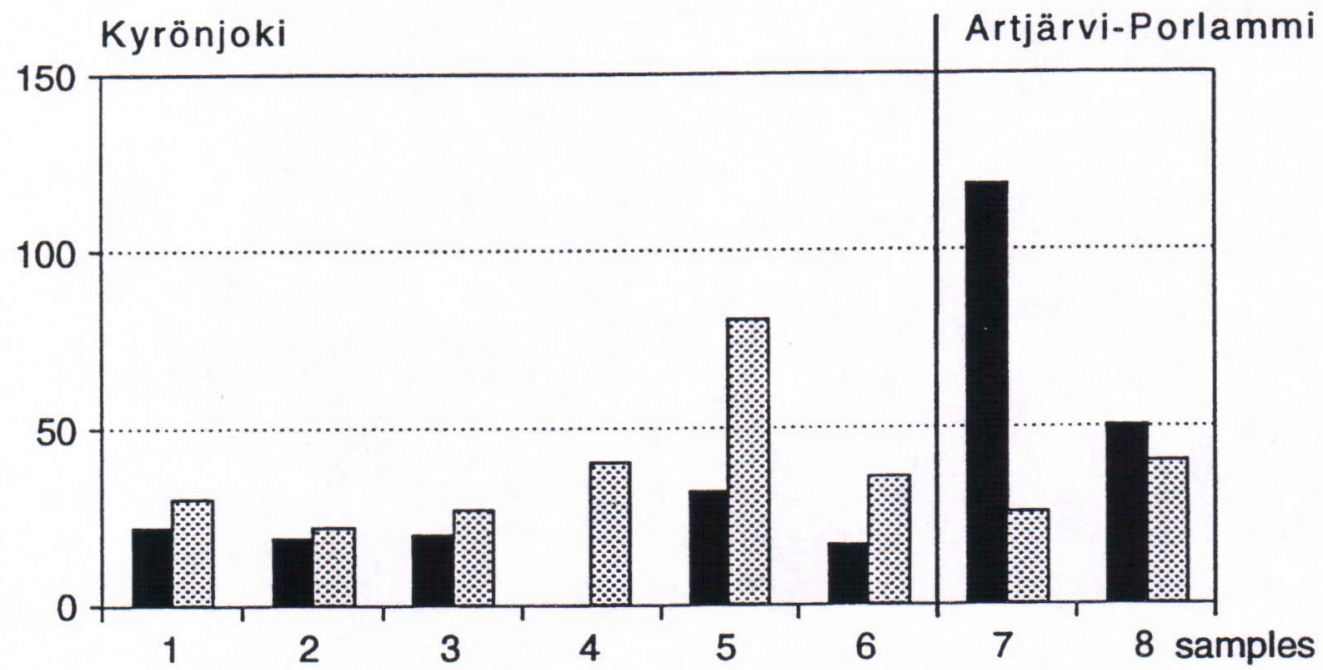

Fig. 6. Chromium content of analyzed milk samples.

$\mathrm{Cu} \mu \mathrm{g} / \mathrm{kg}$

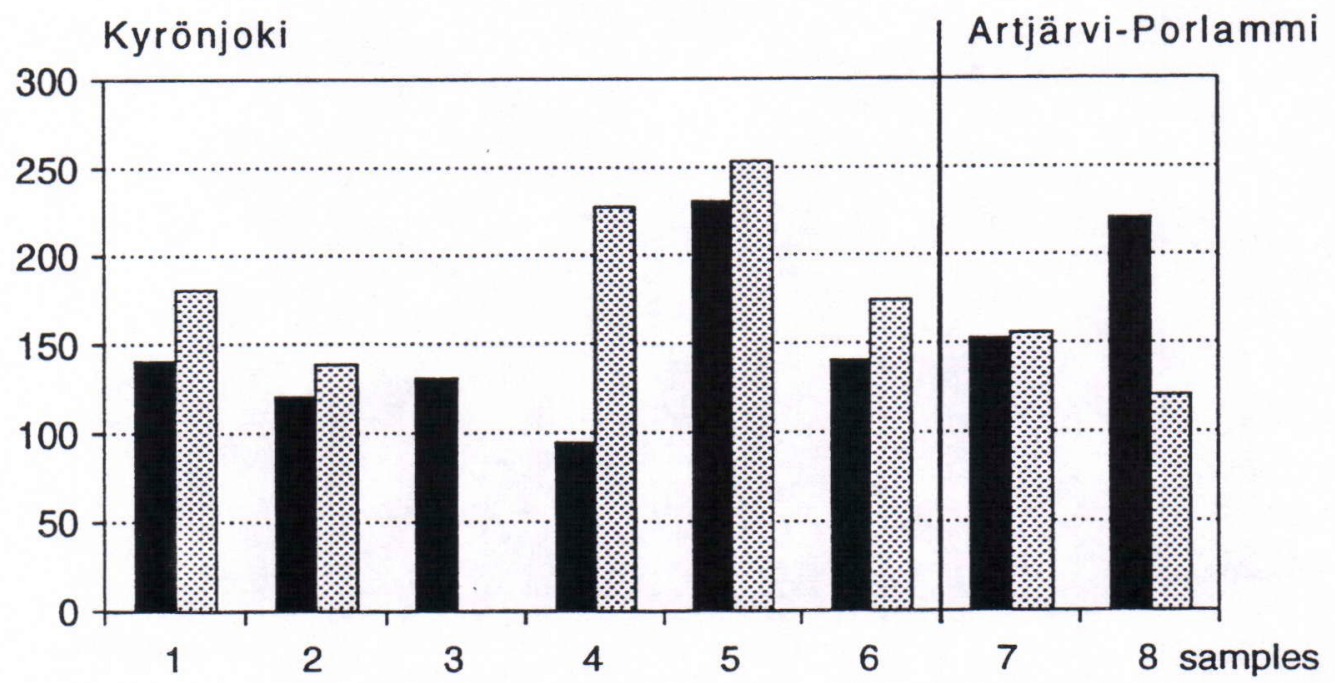

Fig. 7. Copper content of analyzed milk samples. 


\section{$\mathrm{Na} \mathrm{mg} / \mathrm{kg}$}

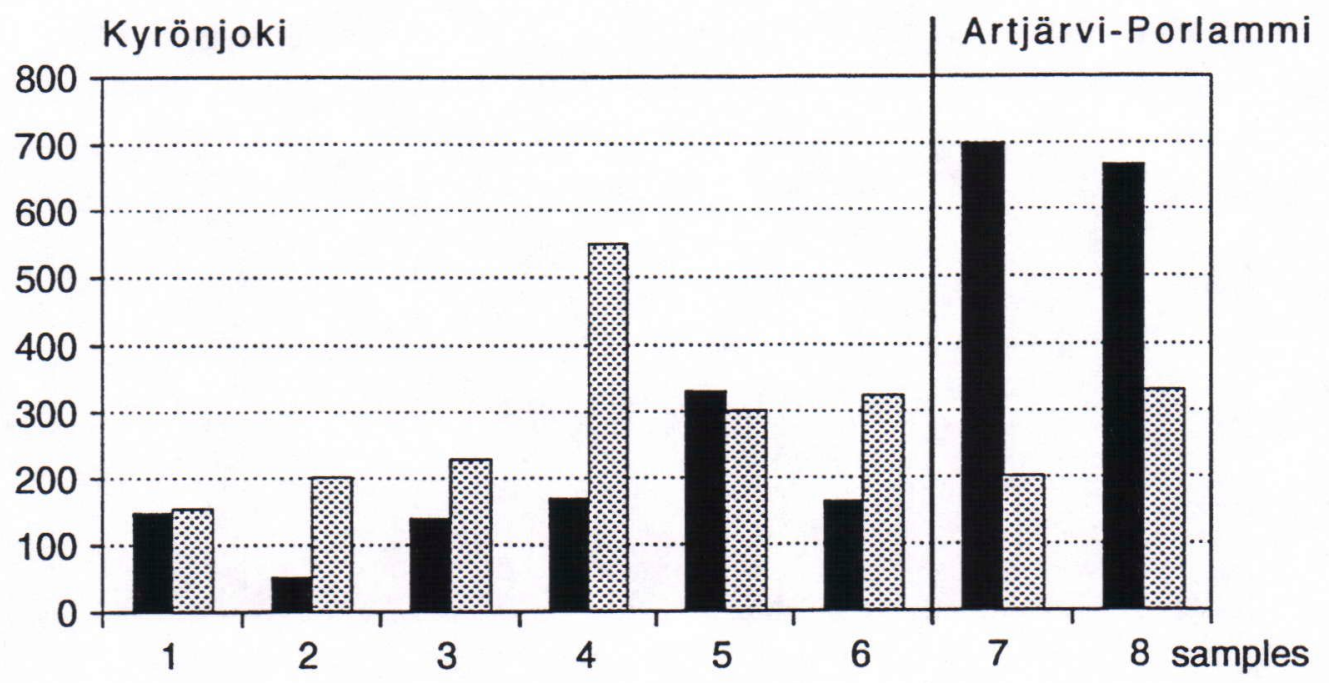

Fig. 8. Sodium content of analyzed milk samples.

\section{$\mathrm{K} \mathrm{mg} / \mathrm{kg}$}

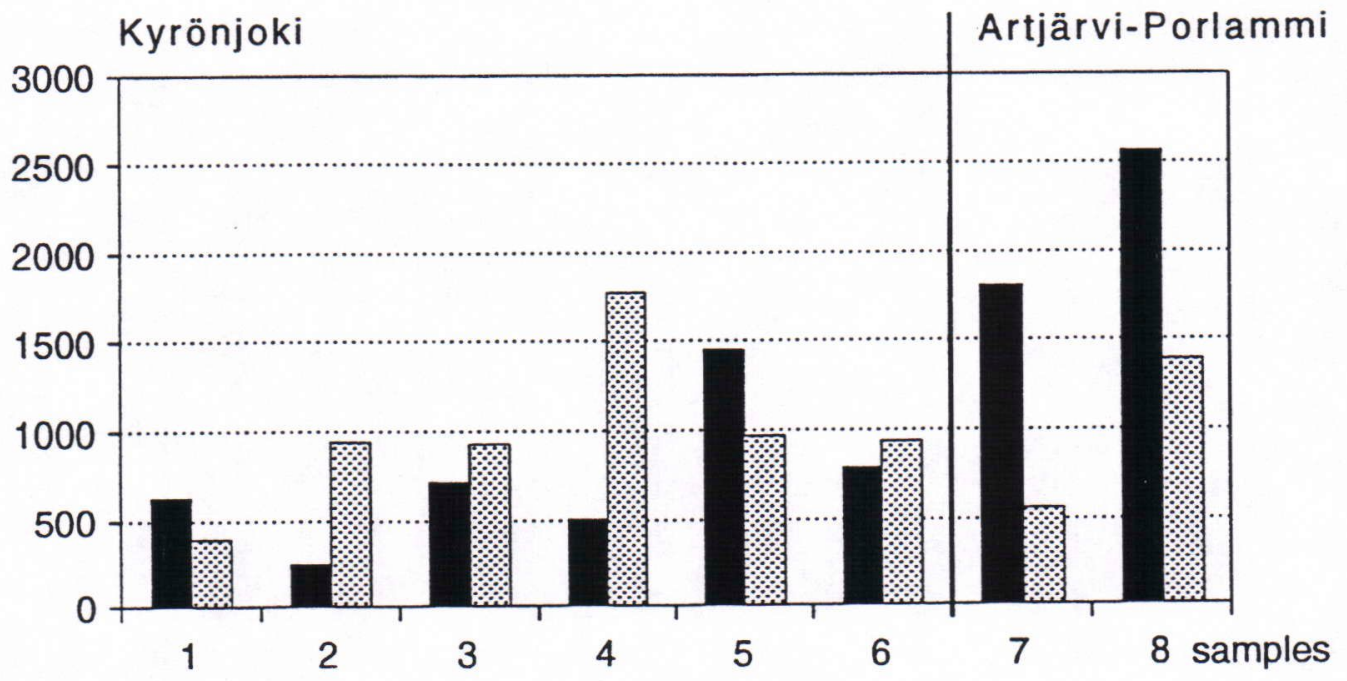

Fig. 9. Potassium content of analyzed milk samples. 


\section{$\mathrm{Mg} \mathrm{mg} / \mathrm{kg}$}

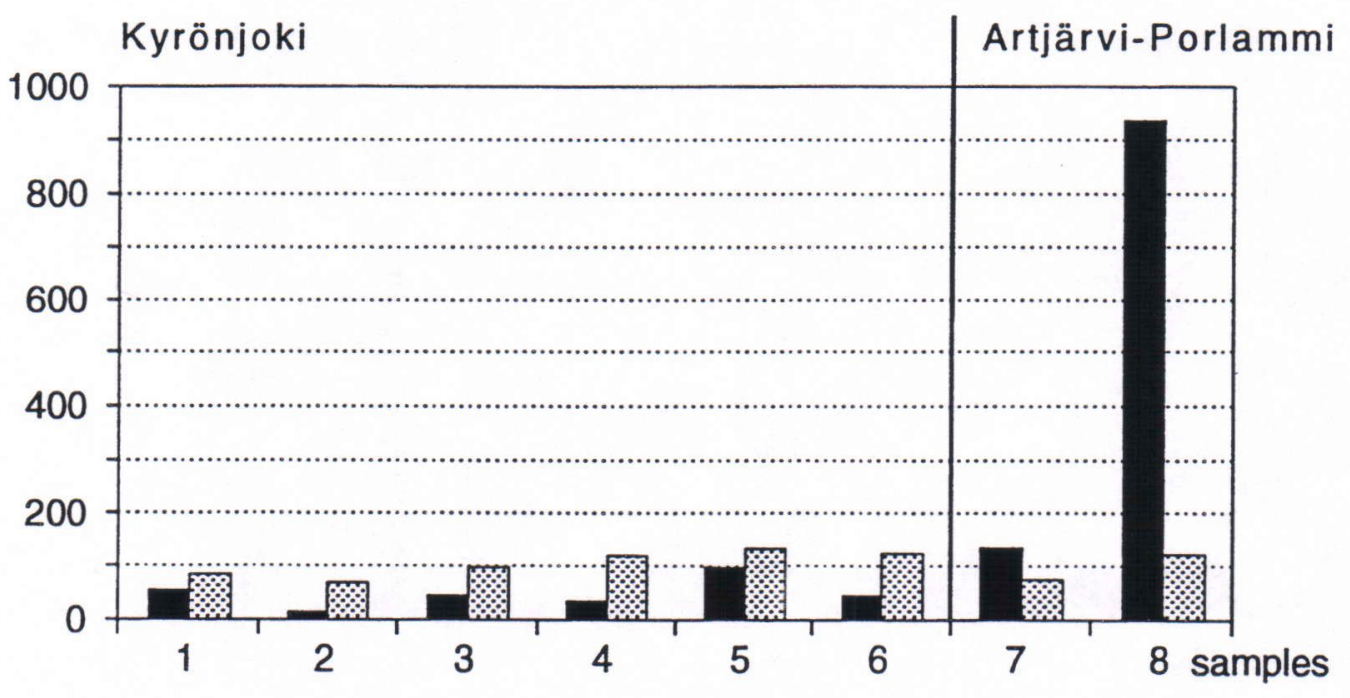

Fig. 10. Magnesium content of analyzed milk samples.

Ca $\mathrm{mg} / \mathrm{kg}$

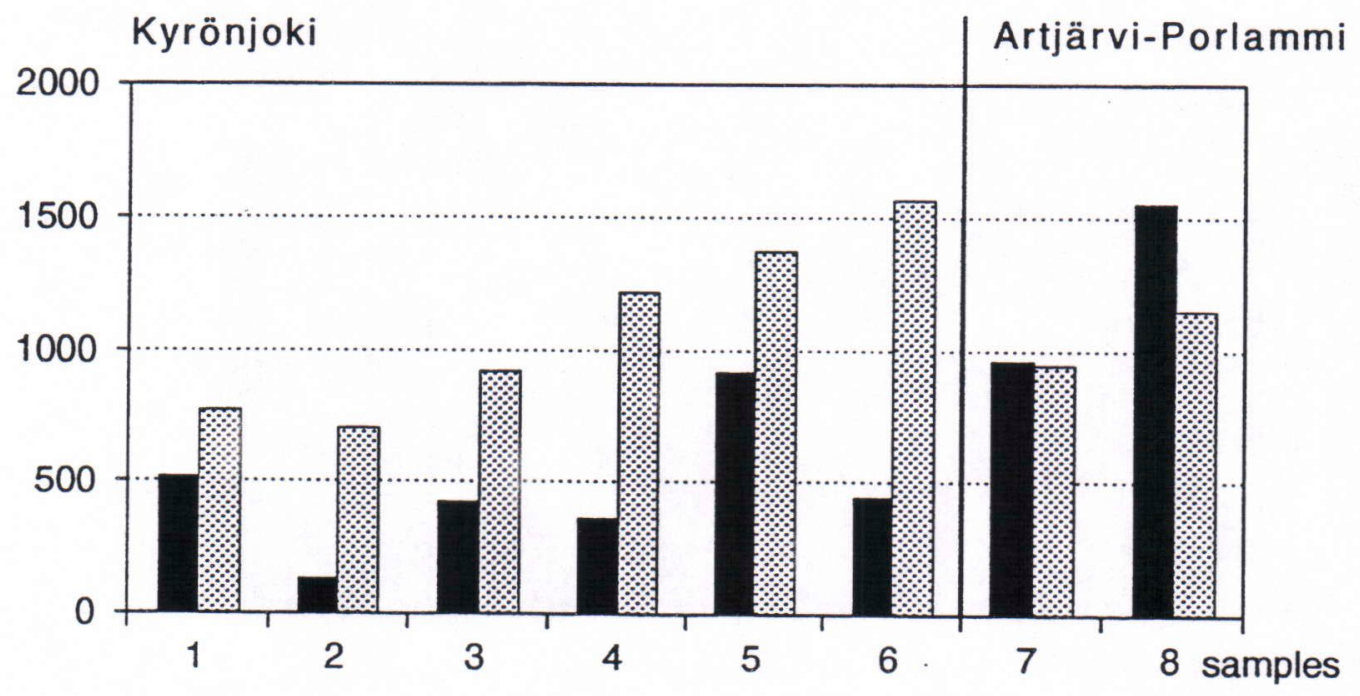

Fig. 11. Calcium content of analyzed milk samples. 


\section{$\mathrm{Ba} \mu \mathrm{g} / \mathrm{kg}$}

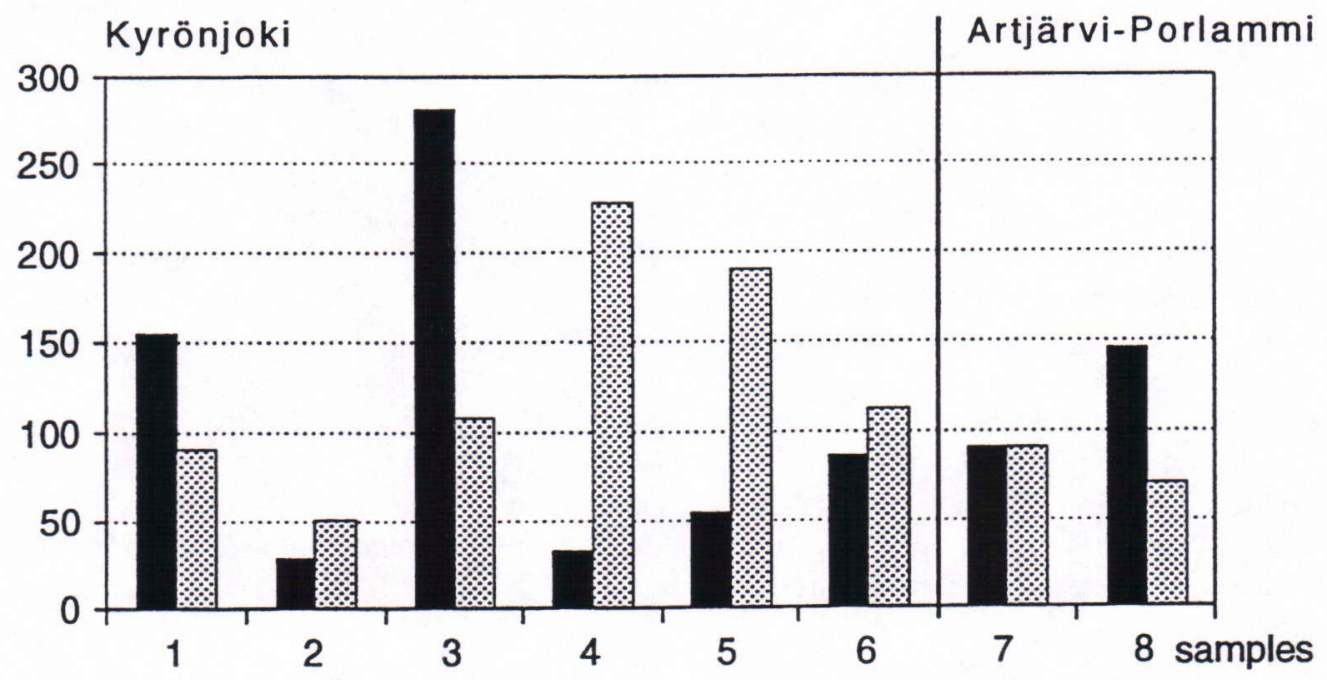

Fig. 12. Barium content of analyzed milk samples.

\section{$\operatorname{Sr} \mu g / k g$}

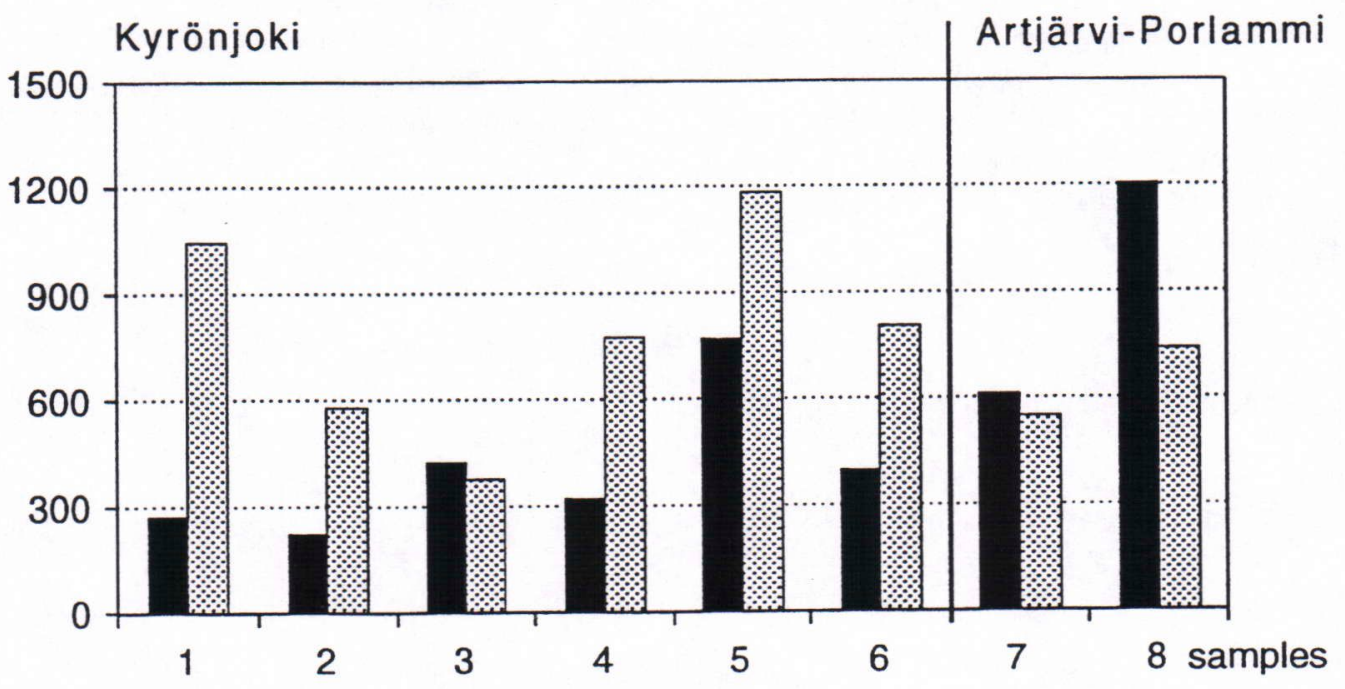

Fig. 13. Strontium content of analyzed milk samples. 


\section{DISCUSSION AND CONCLUSIONS}

The soils of the study areas consist of clayey sediments that were deposited in the Kyrönjoki valley in the Litorina Sea and in the ArtjärviPorlammi area during the lacustrine stage of the Ancylus Lake. It is obvious that they form an inportant source of metals in milk samples studied. The Kyrönjoki area is of special interest because of its sulphate soils (see e.g. Purokoski 1958, Erviö 1975, Mansikkaniemi 1985 and Åström and Björklund 1996). They are characterized by low $\mathrm{pH}$, high sulphur, iron and aluminium concentrations.

Stream and lake water chemistry is clearly controlled by the acid geochemical environment. Elevated concentrations of sulphate, iron, aluminium and other toxic metals have been measured in the water of the river Kyrönjoki (Verta 1984, Eden and Björklund 1993, Lahermo et al. 1995 and Åström and Björklund 1996). Strong acid and nutrient fluxes including heavy metals occur during snowmelt in the area (Meriläinen 1986, Eden and Björklund 1993 and Kuula 1995). This can partly be explained by the sulphide-bearing clays, and when Holocene uplift of land and ditching by man bring large areas of sulphide clays into the oxidation zone, sulphate soils are produced and metals are more easily leached (Björklund 1994). As far as aluminium is concerned its mobilization is controlled by both high humus content and low $\mathrm{pH}$. In acid environment the toxic forms of $\mathrm{Al}$ can be very harmful (Lahermo et al. 1995).
The variations of metal content in the milk samples from the areas of the Kyrönjoki and Artjärvi-Porlammi are not significant except those of aluminium. Its elevated concentrations are most probably associated with the acid geoenvironment in the Kyrönjoki valley. In addition, the values of zinc are higher in the samples of the indoor feeding, which obviously is related to the composition of fodder.

The metal concentrations in our study are relatively high as compared with data from the literature (e.g. Varo et al. 1980 and Blüthgen et al. 1997). Soil is a natural reservoir from which most of the elements are derived. It is also a source of environmental contamination in the food chains. Thus in an acid geoenvironment such as the Kyrönjoki valley certain elements with elevated concentrations are contaminants in milk.

As stated by Häsänen et al. (1986) low soil $\mathrm{pH}$ and high concentrations of soluble iron, zinc, chromium and especially aluminium are associated with a high MS prevalence in the Kyrönjoki area. Thus the toxic metals in milk as well as in potatoes, cereals, vegetables etc. can be added to the source list of this disease. Acid areas, such as the drainage basin of the river Kyrönjoki, constitute a local risk factor of multiple sclerosis (see Irvine et al. 1993). Thus it is probable that in an acid environment the contamination of milk by metals and other trace elements can be a serious geomedical problem. 


\section{REFERENCES}

Antila, P \& Antila, V. (1971) Trace elements in Finnish cow's milk. Suomen Kemistilehti B 44, 161163.

Björklund, A. (1994) Critical load and special characteristics of the Quark area of Finland. In: Raitio, H. \& Kilpinen, T. (eds). Critical loads and critical limit values. Proceedings of the Finnish-Swedish Environmental Conference. Octobre 27-28, 1994, Vaasa, Finland. The Finnish Forest Research Institute. Research Papers 513, 139-150.

Blüthgen, A., Burt, R. \& Heeschen, W. H. (1997) Heavy metals and other trace elements. Monograph on Residues and Contaminants in Milk and Milk Products. IDF Special Issue 9071, 65-73.

Edén, P. \& Björklund, A. (1993) Hydrogeochemistry of river waters in Fennoskandia. Aqua Fennica 23, 2, 125-142.

Erviö, R. (1975) Cultivated sulphate soils in the drainage basin of river Kyrönjoki. Journal of the Scientific Agricultural Society of Finland 47, 550-561.

Heikkilä, R. (1991) The influence of land use on the sedimentation of the river delta in the Kyrönjoki drainage basin. Hydrobiologia 214, 143-147.

Häsänen, E., Kinnunen, E. \& Alhonen, P. (1986) Relationships between the prevalence of multiple sclerosis and some physical and chemical properties of soil. The Science of the Total Environment 58, 263-272.

Irvine, D.G., Robertson, K., Hader, W.J. \& West, R. (1993) Geotoxicology of Multiple Sclerosis: correlation of groundwater chemistry with childhood homes and prevalence of MS patients, Saskatchewan, Canada. Applied Geochemistry, Suppl. Issue 2, 235-240.

Kuula, M. (1995) Raskasmetallien mobiloituminen Itämeren valuma-alueella Suomessa. Geological Survey of Finland, unpublished report, S/42/ 0000/1/1995, $58 \mathrm{pp}$.
Lahermo, P., Mannio, J. \& Tarvainen, T. (1995) The hydrogeochemical comparison of streams and lakes in Finland. Applied Geochemistry 10, 45-64.

Mansikkaniemi, H. (1985) Sedimentation and water quality in the flood basin of the river Kyrönjoki in Finland. Fennia 163, 155-194.

Meriläinen, J.J. (1986) Loads of nutrients, organic matter and suspended solids discharged by the river Kyrönjoki into the Bothnian Bay. Publications of the Water Research Institute, National Board of Waters, Finland. No. 68.

Purokoski, P. (1958) Die schwefelhaltigen Tonsedimente in dem Flachlandgebiet von Liminka im Lichte chemischer Forschung. Agrogeologische Publikationen 70, 76 pp.

Salminen, R., Kukkonen, M., Paukola, T. \& Töllikkö, S. (1997) Chemical composition of clays in southwestem Finland. Geological Survey of Finland, Special Paper 23, 117-126.

Tynni, R., Hyyppä, J. \& Valovirta, V. (1976) Suomen geologinen kartta 1:100 000. Maaperäkartan selitykset. 3022 Lapinjärvi. Lapinjärven kartta-alueen maaperä. Geologian tutkimuslaitos, Espoo 1976, $40 \mathrm{pp}$.

Varo, P., Nuurtamo, M., Saari, E. \& Koivistoinen, P. (1980) Mineral Element Composition of Finnish Foods VIII. Dairy Products, Eggs and Margarine. Acta Agriculturae Scandinavica, Suppl. 22,11S126.

Verta, M. (1984) The effect of watercourse bulding to the heavy metal concentrations in drainage waters. Vesihallituksen monistesarja 220, 74-82 (in Finnish).

Åström, M. (1996) Geochemistry, Chemical Reactivity and Extent of Leaching of Sulphide-bearing Fine-grained Sediments Ostrobothnia, Western Finland. Department of Geology and Mineralogy, Åbo Academi University, 44 p.

Åström, M. \& Björklund, A. (1996) Geochemistry and acidity of sulphide-bearing postglacial sediments of western Finland. Environmental Geochemistry and Health 18. 